\title{
A Semi-Automatic Methodology for Making FMEA Surveys
}

\author{
Christian Spreafico \\ Department of Management Information and Production Engineering, \\ University of Bergamo, Viale Marconi 5, 24044 Dalmine (Bg), Italy. \\ Corresponding author: christian.spreafico@unibg.it \\ Davide Russo \\ Department of Management Information and Production Engineering, \\ University of Bergamo, Viale Marconi 5, 24044 Dalmine (Bg), Italy. \\ E-mail: davide.russo@unibg.it
}

(Received December 14, 2019; Accepted March 26, 2020)

\begin{abstract}
This paper proposes a semi-automatic methodology to assist the user in creating surveys about FMEA and Risk Analysis, based on a customized use of the tools for semantic analysis and in particular a home-developed syntactic parser called Kompat Cognitive. The core of this work has been the analysis of the specific FMEA-related jargon and its common modalities of description within scientific papers and patents in order to systematize the linguistic analysis of the reference documents within the proposed step-divided procedure. The main goals of the methodology are to assist not skilled in the art users about FMEA during the analysis of generic and specific features, by considering large moles of contributions in restricted amounts of time. The methodology has then been tested on the same pool of 286 documents, divided between 177 and 109 patents, manually analyzed in our previous survey, in order to replicate part of its classifications through the proposed new modality. In this way we evaluated the abilities of the methodology both to automatically suggesting the main features of interest and to classify the documents according to them.
\end{abstract}

Keywords- FMEA, Risk analysis, Patents, Parsing, Semantic

\section{Introduction}

Since its introduction in 1949, FMEA had a great following both in industrial and scientific community as testified by the vast multitude of related documents from scientific and patent literature: to date, we have more than 3600 papers only in Scopus DB and 146 patents in Espacenet DB, just looking for one single keyword "FMEA", without synonyms, with a trend of constant growth over the years. The great majority of these contributions deals with FMEA modifications involving the procedure and the integrations with new methods and tools in order to enlarge the field of application and to improve the efficiency of the analysis, e.g. by reducing the required time, by finding more results, etc.

In order to be able to orientate among the many contributions the surveys proposed in literature can play a fundamental role, even if they are limited in the number of considered documents by never exciding one hundred of only scientific papers from journals. Bouti and Kadi (1994) analyzed within scientific papers about FMEA, the description and review of its basic principles, the types, the improvements, the computer automation codes, the combination with other techniques and specific applications. Sutrisno and Lee (2011) analyzed, through a literature survey, the FMEA applications for enhancing service reliability, by determining how FMEA is focused on profit and supply chain-oriented service business practices and FMEA research opportunities are related to enhancement in Risk Priority Number (RPN), reprioritization, versatility of its application in 
International Journal of Mathematical, Engineering and Management Sciences

Vol. 6, No. 1, 79-102, 2021

https://doi.org/10.33889/IJMEMS.2021.6.1.007

service supply chain framework and non-profit service sector as well as combination with other quality control tools are proposed for further investigations. Tixier et al. (2002) studied 62 methodologies about Risk Analysis by separating them into three different phases (identification, evaluation and hierarchisation) and by studying their inputs (plan or diagram, process and reaction, products, probability and frequency, policy, environment, text, and historical knowledge), the implemented techniques for analyze risk (qualitative, quantitative, deterministic and probabilistic) and their output (management, list, probabilistic and hierarchisation). Liu et al. (2013) analyzed the innovative proposed approaches to overcome the limitations of the conventional RPN method within 75 FMEA papers published between 1992 and 2012 by identifying which shortcomings attract the most attention, which approaches are the most popular and the inadequacy of the approaches. Other authors focused on analyzing specific kinds of application of FMEA approach. Dale and Shaw (1990) studied how 78 companies of the United Kingdom motor industry apply FMEA by identifying some common difficulties such as time constraints, poor organizational understanding of the importance of FMEA, inadequate training and lack of management commitment.

An attempt to overcome this limitation has been made by our previous surveys (Spreafico et al., 2017; Spreafico and Russo, 2019a), where we analyzed a representative pool of scientific papers (220) and patents (109), by classifying them into four groups of common improvements dealing with the applicability of the method, representation of the cause and effect chain, risk analysis and integration with the problem-solving phase. Each group has a series of subclasses about the subgoals and the integration (methods and tools).

A common limitation for all these surveys regards their reference time period and the onerousness of execution and updating. To deal with such problems, automatic tools and techniques for text mining can be considered, which can help for different purposes: knowledge source both for papers (e.g. Google Scholar, Scopus) and for patents (e.g. Espacenet), bibliographic search tools implementing different techniques (e.g. Boolean or Semantic logics), tools for managing the documents (e.g. Mendeley), tools for text summarization and topics extraction, software for data representation (e.g. D3.js, Google Charts). However, an automatic methodology to assist the researcher to organize and manage documents about FMEA and Risk Analysis is still missing in literature.

\section{The Procedure of Analysis}

In order to overcome the open problems from the previous survey, we retain that a semi-automatic methodology based on semantic analysis could be a possibility as recently demonstrated for other fields of application, e.g. Sentiment analysis social media monitoring, E-discovery for legal literature and GoPubMed for biomedical texts.

In our case, starting from the same pool of documents from our previous survey (Spreafico et al., 2017), we analyzed them through a home-built software, called Kompat Cognitive (Russo et al., 2018), and we compared the linguistic rules for the linguistic analysis (e.g. logical analysis), with the specific FMEA terminology. Kompat Cognitive is an advanced version of the our previous Kompat, a syntactic Parser that allows to easily set up a sequence of terms and to automatically extract the list of terms linked to it by selecting the semantic relations. This tool has previously been used also in other fields, such as circular economy (Spreafico et al., 2019) and the investigation of the market potential of a product (Russo et al., 2019). 
International Journal of Mathematical, Engineering and Management Sciences

Vol. 6, No. 1, 79-102, 2021

https://doi.org/10.33889/IJMEMS.2021.6.1.007

Through this work we collected some common linguistic forms used to describe FMEA improvements within papers and patents at different levels of detail: pursued goals, specific strategies of intervention and proposed integrations with methods and tools. We have then classified the results within a series of specific steps in order to define a systematic methodology to be automatized.

In the following, the proposed methodology is presented in detail.

\subsection{STEP 1 - Building the Electronic Pool of Documents}

The first step of the proposed methodology regards the digitalization of the documents, where the required output files are related to the used tools, both as regard the format, the syntactic and the organization of the content within specific text tags. In our case, we opted for the definition of a single textual file (i.e. XML) for each document, which must to be named with a univocal ID name, in order to allow the user to go trace back the document containing a determined content. The content of the electronic document is instead organized through text fields, including specific parts of the documents (e.g. introduction, state of the art and proposal), so as to allow the analysis of some parts. In this way during the enumerations of the specific proposed contributions we can avoid redundancies present within the state of the art of the considered documents. A limitation of these files concerns the impossibility to process images, tables and graphs but only the semantic relations within the sentences.

\subsection{STEP 2 - Query Definition}

Once the electronic pool has been defined it has to upload on the server and can be processed by Parser tool, in response to a query, consisting of a single keyword (e.g. name, verb, adjective) defined by the user, provides the main linguistic relations between the keyword and other terms (e.g. subjects, verbs, objects). These relations are identified within the single sentences of the processed documents and they also include the relations with modifiers of the keyword (e.g. synonyms, meronyms, hypernyms) that are identified on the basis of statistical patterns based on the considered pool. The kinds of identified relations by the Parser are different depending on the linguistic nature of the used keyword.

If we use a substantive (e.g. FMEA), the software provides: (1) the modifiers, or the adjectives or the substantives acting as adjectives (e.g. Design FMEA, Economic-Based FMEA), (2) the nouns and verbs modified by the keyword (e.g. FMEA template), (3) verbs using the keyword used as object (e.g. perform FMEA), (4) verbs with the keyword used as subject (e.g. FMEA is ..., FMEA generates ...), (5) substantives linked to the keyword through AND/OR relations (e.g. FMEA and TRIZ - Spreafico and Russo, 2019b) and (6) prepositional phrases (e.g. ... of FMEA, ... through FMEA). While, when we use a verb as keyword, we can instead identify: (1) the modifiers (e.g. effectively improve), (2) the objects (e.g. ... improve quality, ... improve design), (3) the subjects (e.g. TRIZ improves ...) and (4) other particles (i.e. prepositions and adverbs) used before or after the verb (e.g. determine AND select). Thus, each provided linguistic relation can be manually checked by the user: by selecting it, the tool provides the list of the sentences of the documents of the pool, which contain it. In this way, we can verify their adherence in relation to the purposes and the context of the research.

However, although the qualitative level (precision) of the analysis along with the quantity of the provided results (recall) achieved through the Parser proved to be more than acceptable in several applications from different fields, some considerations about this specific case, and in particular 
International Journal of Mathematical, Engineering and Management Sciences

Vol. 6, No. 1, 79-102, 2021

https://doi.org/10.33889/IJMEMS.2021.6.1.007

regarding FMEA jargon, in order to systematize and automatize the approach.

Our main focus was then to identify the common linguistic ways along with the specific terminology used within FMEA related documents to declare interesting concepts (e.g. goal, strategies and tools). The first step regarded the definition of the terminology. Among them, we identified generic verbs (e.g. Improve, Ameliorate, Reduce) that are generally used to introduce the goals of the proposed interventions, which in turn are expressed by generic terms (e.g. costs, time, production), or strategies for improving FMEA tasks, which are instead expressed through FMEArelated terms (e.g. Failure, Modes, Effects).

Table 1 summarizes the main terms that can be used as keywords to start the analysis, which have been enriched with synonyms and other terms that iteratively emerged during the analysis as explained in the following (Step 3).

Table 1. Initial keywords used to search the queries.

\begin{tabular}{|c|c|c|}
\hline \multicolumn{2}{|c|}{ Generic terms } & \multirow{2}{*}{ FMEA terms } \\
\hline Nouns & Verbs & \\
\hline $\begin{array}{l}\text { FMEA, Human, Approach, Design, } \\
\text { Production, Maintenance, Time, Costs, } \\
\text { Problem }\end{array}$ & $\begin{array}{l}\text { Improve, Anticipate, Ameliorate, } \\
\text { Automatize, Analyze, Reduce, } \\
\text { Eliminate, Solve }\end{array}$ & $\begin{array}{l}\text { Failures, Modes, Effects, Cause, Risk, } \\
\text { Solving, Decision making }\end{array}$ \\
\hline
\end{tabular}

Then, we searched for the common linguistic constructions, involving prepositions (e.g. by, for), more articulated constructs (e.g. with the aim to) and the identified terms (verbs and nouns), and we analyzed their ways of use within the documents (e.g. introduce a tool, a goal, a strategy or relate these terms among them). As result, some common forms have been identified.

The construct "In order to" (see Figure 1) is generally used to explain the reason why a determined integration, e.g. a method or a tool, has been introduced to improve FMEA: to achieve a generic goal (e.g. reduce the required time for the application of the method) or to pursue a strategy (e.g. Determine More Failures through schematic representation). We noted that both of them are expressed through a verb with infinite form and an object. In addition, "In order to" can be followed by the particles "for" or "by", respectively coupled with a name or a verb in "-ing" form to introduce another strategy or another goal.

IN ORDER TO ... FORM

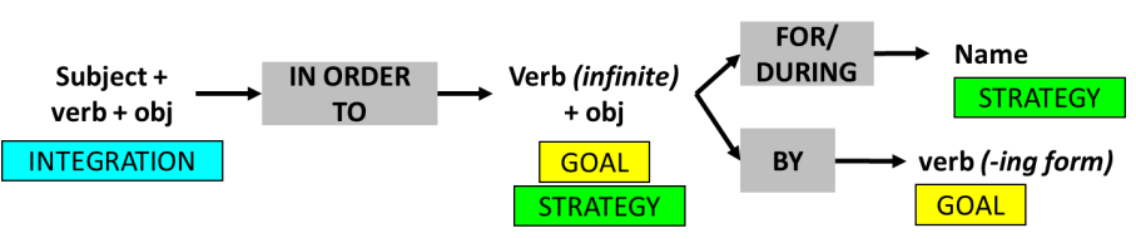

Examples:

- The proposed method integrates Fuzzy logic IN ORDER TO reduce user's subjectivity FOR risk analysis

- The proposed method integrates Fuzzy logic IN ORDER TO improve risk evaluation phase BY reducing user's subjectivity

Figure 1. Common uses of "in order to ..." form. 
International Journal of Mathematical, Engineering and Management Sciences

Vol. 6, No. 1, 79-102, 2021

https://doi.org/10.33889/IJMEMS.2021.6.1.007

The constructs "With the aim of" and "With the goal of" (Figure 2) is also exploited for express the goals and the strategies related to a determined integration (methods and tools) and to relate a strategy with a goal or vice versa.

WITH THE AIM/GOAL OF ... FORM

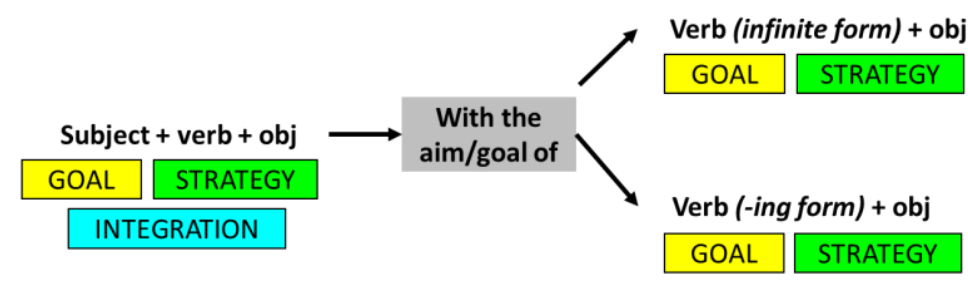

Examples:

- The proposed method integrates Fuzzy logic with the aim to reduce user's subjectivity

Figure 2. Common uses of the constructs "With the aim of ..." and "With the goal of ...".

Other constructs are instead related to the declaration of the goals (Figure 3) of the proposed FMEA modifications. They are the prepositions "Through" and "By", which are used after the declaration of the goal itself, expressed (through a verb and an object) to relate an integration or a strategy. Finally, the particle "For" has been used sometimes after the integration, preceded by the preposition "by", to introduce the related strategy, in turn expressed through a name.

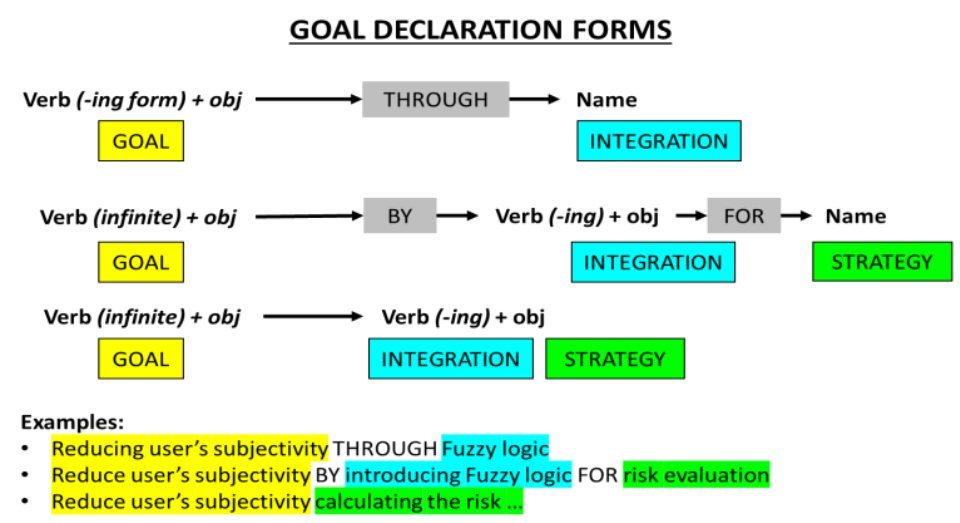

Figure 3. Common linguistic forms identified for declaring the goals of the proposed FMEA modifications.

\subsection{STEP 3 - Semantic Expansion and Counting of the Number}

The activity carried constitutes the basis both to automatically identify the main interesting features of interest and to classify the documents according to them. However, in order to obtain a significant result regarding the document classification, the set of the identified terms has to be expanded by considering also the synonyms and other terms. In fact, the same concept can be 
International Journal of Mathematical, Engineering and Management Sciences

Vol. 6, No. 1, 79-102, 2021

https://doi.org/10.33889/IJMEMS.2021.6.1.007

expressed within the documents in a multitude of different textual forms that generally increase if the investigated concept itself is more abstract.

Table 2 shows, as example, some of the combinations of verbs and objects used to express the concept "Solve problem", found within the considered pool of documents.

Table 2. Synonyms of "Solve problem" found within the considered pool of documents.

\begin{tabular}{|l|l|l|}
\hline \multicolumn{2}{|c|}{ Solve } \\
\hline Eliminate & Overcome & Avoid \\
\hline Deal with & Mitigate & Address \\
\hline Prevent & Cause & $\ldots$ \\
\hline \multicolumn{2}{|l|}{ Problem } \\
\hline Issue & Drawback & Challenge \\
\hline Trouble & Limitation & Deficiency \\
\hline Disadvantage & Anomaly & $\ldots$ \\
\hline
\end{tabular}

Carrying out a linguistic expansion manually is undoubtedly a difficult and onerous task and some considerations must be taken into account. For what concern the expansion of generic terms, i.e. verbs (e.g. Solve) and common names (e.g. Interface, Design), a simple dictionary can be sufficient to achieve acceptable results, while for those specific nouns and concepts related to FMEA (e.g. Root Causes) and their integrations (e.g. Quality Function Deployment), the knowledge about the argument is required. This because they are often referred also through their multiple acronyms: e.g. TRIZ methods can be reported as "Theory of Inventive Problem Solving", "TIPS", "Theory of the resolution of invention-related tasks". Moreover, there are also some variants of the methods that are typically used in different applications: table 3 reassumes some applications of Fuzzy logic, which have been identified by the Parser, by analysing the reference FMEA pool of documents.

Table 3. Examples of applications of "Fuzzy logic" found within the considered pool of documents.

\begin{tabular}{|l|l|}
\hline Nouns and verbs modified by "fuzzy" & "fuzzy" and/or ... \\
\hline Fuzzy Membership Function & Triangular Fuzzy Number \\
Fuzzy Analytic Hierarchy Process & Fuzzy Weighted Geometric Mean \\
Fuzzy Cognitive Map & Fuzzy linguistic terms \\
Fuzzy Decision Matrix & Fuzzy linear programming model \\
Fuzzy Group Fault & Trapezoidal fuzzy numbers \\
Fuzzy Set Theory & Fuzzy evidential reasoning \\
\hline
\end{tabular}

The main problem of the manual expansion of the synonyms of methods and tools is the excessive required amount of time, which typically increases when the analyst is less expert. In addition, if the process is carried out a priori can be useless, because the expansion of the synonyms, not knowing those effectively used within the pool, can digresses through extraneous terms. Fortunately, some of the available tools for semantic analysis, and the Parser, are able to automatically identify the modifiers of the used keywords within the considered pool, with a sufficient degree of accuracy. This functionality is also particularly useful to discriminate specific uses of the variants of the integrations in relation to the context of use.

Figure 4 shows how Fuzzy Logic and Fuzzy Membership Function have been related to different 
International Journal of Mathematical, Engineering and Management Sciences

Vol. 6, No. 1, 79-102, 2021

https://doi.org/10.33889/IJMEMS.2021.6.1.007

goals by the Parser.

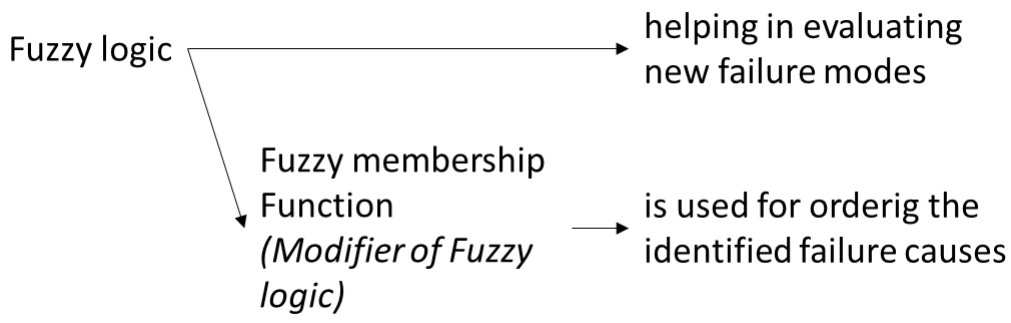

Figure 4. Identification of different goals from FMEA integrations with "Fuzzy logic" and "Fuzzy Membership Function".

\section{Case Study}

In order to test the efficacy of the proposed methodology, we replied the manual classification of the solutions (i.e. strategies) to improve FMEA, from our previous survey (Spreafico et al., 2017) by comparing the obtained results. That previous survey was made on a pool constituted by 286 documents, 177 scientific papers (165 from academia and 12 from industry) and 109 patents (23 from academia and 86 from industry), collected from scientific DBs (i.e. SCOPUS) and international patents DBs (i.e. Espacenet).

Table 4 presents the considered classification about the main problems (Applicability, Cause and Effects Chain representation, Risk Analysis and Problem Solving) and the solutions to improve them identified from literature, with the total number of documents related to each of them.

Table 4. Main problems and solutions to improve FMEA, from Spreafico et al. (2017).

\begin{tabular}{|l|l|c|c|c|}
\hline \multirow{4}{*}{ Problems } & \multicolumn{1}{|c|}{ Solutions } & \multicolumn{2}{c|}{$\begin{array}{c}\text { Number of citations in } \\
\text { papers/patents }\end{array}$} \\
\cline { 2 - 4 } & \multicolumn{1}{|c|}{$\begin{array}{c}\text { Accad. } \\
\text { Ind. }\end{array}$} & \multicolumn{1}{c|}{ Total } \\
\hline \multirow{5}{*}{ Applicability } & $\begin{array}{l}\text { Anticipate the analysis: Integrate FMEA with design methods } \\
\text { in order to anticipate it during design phase (Liu et al., 2011) }\end{array}$ & 54 & 18 & 72 \\
\cline { 2 - 5 } & More automation (Price and Taylor, 1998) & 34 & 19 & 53 \\
\cline { 2 - 5 } & $\begin{array}{l}\text { Info management: Improve management of the information } \\
\text { through matrix and graphical representations }\end{array}$ & 38 & 10 & 48 \\
\cline { 2 - 5 } & $\begin{array}{l}\text { Guidelines: Introduce new guidelines to explain the sequence } \\
\text { of application and the single steps. }\end{array}$ & 28 & 12 & 40 \\
\cline { 2 - 5 } & $\begin{array}{l}\text { Complex systems: Introduce criteria to approach complex } \\
\text { systems by analysing all the components. }\end{array}$ & 16 & 5 & 21 \\
\cline { 2 - 5 } & $\begin{array}{l}\text { User interface: Ameliorate user interface by providing data } \\
\text { filing template (Price, 1996) }\end{array}$ & 10 & 9 & 19 \\
\cline { 2 - 5 } & $\begin{array}{l}\text { New criteria: Introduce criteria to approach complex systems } \\
\text { by reduce the number of ITEMS to be analysed (Regazzoni and } \\
\text { Russo, 2011) }\end{array}$ & 3 & 2 & 5 \\
\hline
\end{tabular}


International Journal of Mathematical, Engineering and Management Sciences

Vol. 6, No. 1, 79-102, 2021

https://doi.org/10.33889/IJMEMS.2021.6.1.007

Table 4 continued ...

\begin{tabular}{|c|c|c|c|c|}
\hline \multirow{4}{*}{ Cause and effects representation } & New methods for Failure Modes identification (Lee, 2001a) & 35 & 30 & 65 \\
\hline & $\begin{array}{l}\text { New methods for Failure Effects: increase the number of } \\
\text { determined Failure Effects (Xiao et al., 2011) }\end{array}$ & 30 & 13 & 43 \\
\hline & $\begin{array}{l}\text { Combine multiple Failures Effects, studying the result and } \\
\text { the possible synergies (Price and Taylor, 1998) }\end{array}$ & 18 & 8 & 26 \\
\hline & $\begin{array}{l}\text { New methods for Failure Causes: Increase the number of the } \\
\text { determined Failure Cause, including root causes (Yang et al., } \\
\text { 2010) }\end{array}$ & 10 & 5 & 15 \\
\hline \multirow{5}{*}{ Risk analysis } & $\begin{array}{l}\text { Statistical methods: quantify statistically and logically the } \\
\text { probability of the faults }\end{array}$ & 68 & 10 & 78 \\
\hline & $\begin{array}{l}\text { Requirements-based criteria: New measure to evaluate the } \\
\text { risks based on the analysis of the requirements }\end{array}$ & 25 & 6 & 31 \\
\hline & $\begin{array}{l}\text { Economic criteria: quantify the potential faults according to } \\
\text { economic criteria (Rhee and Ishii, 2003) }\end{array}$ & 13 & 3 & 16 \\
\hline & $\begin{array}{l}\text { Historical data: quantify the potential faults according to } \\
\text { historical data (Garcia and Gilabert, 2011) }\end{array}$ & 9 & 5 & 14 \\
\hline & $\begin{array}{l}\text { Qualitative criteria: Analyse qualitatively the risk, using } \\
\text { personal judgments and impressions instead of aseptic } \\
\text { measurements and numerical ratings (Kara-Zaitri et al., 1991) }\end{array}$ & 1 & 4 & 5 \\
\hline \multirow{3}{*}{ Problem solving } & $\begin{array}{l}\text { Results representation: Improve presentation of the results } \\
\text { by changing the interface of presentation. }\end{array}$ & 27 & 7 & 34 \\
\hline & $\begin{array}{l}\text { New methods to be integrated into FMEA (TRIZ, } \\
\text { Maintenance management tools, etc.) (Liu et al., 2011) }\end{array}$ & 19 & 10 & 29 \\
\hline & Use FMEA for other purposes (i.e. robust design) & 3 & 5 & 8 \\
\hline Total & & 441 & 181 & 622 \\
\hline
\end{tabular}

In order to make an objective evaluation, we applied the proposed methodology on the same pool of documents of our previous survey. So, we executed two different tests: TEST 1 aimed to investigate the ability of the proposed methodology to automatically identify the features of interest for the analysis (TEST 1) and TEST 2 to evaluate ability of the methodology in classify the documents according to the features.

\subsection{Results}

\subsubsection{TEST 1. Identifying the Features}

During this first test, we used simple generic keywords consisting of common nouns (e.g. FMEA, Failures, Guidelines) and we considered only one semantic structure where the keywords are used as object in relation to the verbs automatically provided by the Parser. The test is considered positive if the Parser is able to suggest relations referred to the features (Problems) of the previous survey. As further confirmation, we manually checked the sentences of the documents provided by the Parser for each relation in order to verify their adherence with the relative feature.

Table 5 collects, for each previously determined feature, the used keywords, the considered relations and the pertinent sentences. As first confirmation of the goodness of the methodology, from the table, we can see that for each feature, one pertinent sentence has been determined. 
International Journal of Mathematical, Engineering and Management Sciences

Vol. 6, No. 1, 79-102, 2021

https://doi.org/10.33889/IJMEMS.2021.6.1.007

Table 5. Investigated solutions, used queries and obtained sentences.

\begin{tabular}{|c|c|c|c|}
\hline $\begin{array}{l}\text { Features } \\
\text { ("Solutions" } \\
\text { from previous } \\
\text { survey) }\end{array}$ & $\begin{array}{l}\text { Query (used } \\
\text { keywords) }\end{array}$ & $\begin{array}{l}\text { Identified relation } \\
\text { (verb + keyword) }\end{array}$ & Identified sentence \\
\hline $\begin{array}{l}\text { Anticipate the } \\
\text { analysis }\end{array}$ & Design & Improve design & $\begin{array}{l}\text { "conventional design FMEA is often performed by the design team" } \\
\text { (Kmenta and Ishii, 2004) } \\
\text { "in producing the parts and to simplify and improve the design" (Teng } \\
\text { and Ho, 1996) }\end{array}$ \\
\hline $\begin{array}{l}\text { More } \\
\text { automation }\end{array}$ & FMEA & Automate FMEA & $\begin{array}{l}\text { "proposed a concept for automated FMEA employing qualitative } \\
\text { reasoning" (Kmenta and Ishii, 1998) }\end{array}$ \\
\hline $\begin{array}{l}\text { Info } \\
\text { management }\end{array}$ & Information & $\begin{array}{l}\text { Manage } \\
\text { information }\end{array}$ & $\begin{array}{l}\text { "systemically manage the FMECA information of each part" (Lee, } \\
2001 \mathrm{~b} \text { ) }\end{array}$ \\
\hline Guidelines & Guidelines & Provide guidelines & $\begin{array}{l}\text { "The method of this invention provides a few innovative guidelines to } \\
\text { the implementation of a DFMEA technique" (Cutuli et al., 2001; U.S. } \\
\text { Patent No. 10,330,485) }\end{array}$ \\
\hline $\begin{array}{l}\text { Complex } \\
\text { systems }\end{array}$ & Systems & $\begin{array}{l}\text { Analyze complex } \\
\text { systems }\end{array}$ & $\begin{array}{l}\text { "The framework has been applied to model and analyze a complex } \\
\text { industrial system from a paper mill" (Sharma et al., 2008) }\end{array}$ \\
\hline User interface & User & $\begin{array}{l}\text { Provide user } \\
\text { interface }\end{array}$ & $\begin{array}{l}\text { "this methodology and provide a user interface to combine all the } \\
\text { methods used in it" (Hassan et al., 2010) }\end{array}$ \\
\hline New criteria & Criteria & Propose criteria & $\begin{array}{l}\text { "Table VIII reports the pairwise comparisons given by the } \\
\text { maintenance staff in terms of the four criteria proposed for the failure } \\
\text { cause analysis problem" (Boggarapu et al., 2001; U.S. Patent No. } \\
13,113,593 \text { ) }\end{array}$ \\
\hline $\begin{array}{l}\text { New methods } \\
\text { for Failure } \\
\text { Modes }\end{array}$ & Failures & $\begin{array}{l}\text { Identify failure } \\
\text { modes }\end{array}$ & $\begin{array}{l}\text { "The proposed method uses behavior modeling to map control } \\
\text { functions to physical entities and identifies failure modes" (Kmenta and } \\
\text { Ishii, 1998) }\end{array}$ \\
\hline $\begin{array}{l}\text { New methods } \\
\text { for Failure } \\
\text { Effects }\end{array}$ & Failures & $\begin{array}{l}\text { Determine failure } \\
\text { effects }\end{array}$ & $\begin{array}{l}\text { "to determine the failure effects of the underlying component failure } \\
\text { modes by means of the fault simulation analysis method; finally, the } \\
\text { redundancy is solved by the hazard analysis method which takes into } \\
\text { account the effects of multiple faults Inaccurate system analysis" (Chen } \\
\text { et al., 2013; Chinese patent No. CN } 10632162(\mathrm{~A}) \text { ) }\end{array}$ \\
\hline $\begin{array}{l}\text { Combine } \\
\text { multiples } \\
\text { Failure Effects }\end{array}$ & Failures & $\begin{array}{l}\text { Consider multiple } \\
\text { failures }\end{array}$ & $\begin{array}{l}\text { "The new procedure allows for the consideration of multiple failures } \\
\text { while retaining all the characteristics of FMEA" (Pickard et al., 2005) }\end{array}$ \\
\hline $\begin{array}{l}\text { New methods } \\
\text { for Failure } \\
\text { Causes }\end{array}$ & Failures & $\begin{array}{l}\text { Identify failure } \\
\text { causes }\end{array}$ & $\begin{array}{l}\text { "It is a methodological tool which allows identifying and describing } \\
\text { the failures scenarios for a given product or service, At the same } \\
\text { time, ..., identifies the causes" (Laaroussi et al., 2007) }\end{array}$ \\
\hline $\begin{array}{l}\text { Statistical } \\
\text { methods }\end{array}$ & Method & $\begin{array}{l}\text { Approach statistical } \\
\text { methods }\end{array}$ & $\begin{array}{l}\text { "Failure prognostics has been approached via a variety of techniques } \\
\text { ranging from probabilistic / statistical methods" (Abbas and } \\
\text { Vachtsevanos, 2009) }\end{array}$ \\
\hline $\begin{array}{l}\text { Requirements- } \\
\text { based criteria }\end{array}$ & Requirements & $\begin{array}{l}\text { Identify } \\
\text { requirements }\end{array}$ & $\begin{array}{l}\text { "The first starts by identifying functional requirements and continues } \\
\text { with performing a safety analysis, such as a Fault Tree Analysis, in } \\
\text { order to identify non-expected system behavior" (Guo and } \\
\text { Liggesmeyer, 2013; U.S. Patent No. 13,181,681) }\end{array}$ \\
\hline $\begin{array}{l}\text { Economic } \\
\text { criteria }\end{array}$ & Costs & Analyze costs & $\begin{array}{l}\text { "exemplary graphical user display showing cost analyzed and } \\
\text { prioritized failure modes using the data" (Conchieri et al., 2009; U.S. } \\
\text { Patent No. } 11,859,199 \text { ) }\end{array}$ \\
\hline Historical data & Data & Are historical data & $\begin{array}{l}\text { "The information used can be historical data, theoretical analysis, } \\
\text { expert opinions and the attitude of interested parties" (Petrovic et al., } \\
\text { 2014) }\end{array}$ \\
\hline $\begin{array}{l}\text { Qualitative } \\
\text { criteria }\end{array}$ & Analysis & $\begin{array}{l}\text { Perform qualitative } \\
\text { analysis }\end{array}$ & $\begin{array}{l}\text { "performing a sequence based qualitative risk analysis to identify a } \\
\text { plurality of safety critical" (Guo and Liggesmeyer, 2013; U.S. Patent } \\
\text { No. 13,181,681) }\end{array}$ \\
\hline $\begin{array}{l}\text { Results } \\
\text { representation }\end{array}$ & Failures & $\begin{array}{l}\text { Improve failures } \\
\text { representation }\end{array}$ & $\begin{array}{l}\text { "The purpose of scenario-based FMEA is to improve the } \\
\text { representation of failures" (Kmenta and Ishii, 2000) }\end{array}$ \\
\hline New methods & Method & $\begin{array}{l}\text { Adopt TRIZ } \\
\text { method }\end{array}$ & $\begin{array}{l}\text { "To solve contradiction in order to improve service quality, we can } \\
\text { adopt TRIZ method" (Wirawan and Ayu, 2014) }\end{array}$ \\
\hline $\begin{array}{l}\text { Use FMEA for } \\
\text { other purposes }\end{array}$ & FMEA & Use FMEA for ... & $\begin{array}{l}\text { "Using FMEA for early robustness analysis of Web-based systems" } \\
\text { (Zhou et al., 2012) }\end{array}$ \\
\hline
\end{tabular}


International Journal of Mathematical, Engineering and Management Sciences

Vol. 6, No. 1, 79-102, 2021

https://doi.org/10.33889/IJMEMS.2021.6.1.007

\subsubsection{TEST 2: Counting the Results}

During the second test, we evaluate the ability of the methodology in classifying the documents according to the determined features. In order to check this functionality, we used specific keywords for each feature and we manually checked the sentences provided for the main linguistic relations between the keywords and their modifiers with other terms. For each sentence that has been considered pertinent with a certain feature, we traced back the corresponding document through its univocal ID. For instance, in order to identifying those documents dealing with the feature "Anticipate the analysis", we used the keyword "Anticipate", we analyzed the relations "Anticipate DURING ...", "Anticipate AND/OR prevent ..." etc., and we checked the identified sentences from the documents that, for the sake of brevity, in the table are reported with an associated number that can be found in the legend.

Table 6 collects the achieved results: the features, with the number of related components from previous survey, the used keywords, the selected linguistic relations, the pertinent documents (references and total number) for each feature and the index of efficacy (expressed in percentage).

Table 6. Investigated solutions, used queries and identified documents.

\begin{tabular}{|c|c|c|c|c|c|}
\hline $\begin{array}{l}\text { Features } \\
\text { ("Solutions" from } \\
\text { previous survey) }\end{array}$ & \begin{tabular}{|l} 
Total \\
number of \\
documents \\
(from \\
previous \\
survey) \\
\end{tabular} & Query & $\begin{array}{l}\text { Related documents (only selected } \\
\text { papers) }\end{array}$ & \begin{tabular}{|l} 
Total number \\
of documents \\
identified \\
through teh \\
proposed \\
methodology \\
\end{tabular} & $\begin{array}{l}\text { Efficac } \\
\text { y Index }\end{array}$ \\
\hline $\begin{array}{l}\text { Anticipate the } \\
\text { analysis }\end{array}$ & 72 & $\begin{array}{l}\text { anticipate: * during, * } \\
\text { failures, *mode, } \\
\text { *scenario, * problem, * } \\
\text { AND/OR evaluate, * } \\
\text { AND/OR eliminate, } \\
\text { *AND/OR prevent } \\
\text { design: * FMEA, } \\
\text { product *, * product, * } \\
\text { reliability, * system, * } \\
\text { part, * measure, * } \\
\text { AND/OR implement, * } \\
\text { AND/OR manufacturing, } \\
\text { * FOR ..., * INTO ..., * } \\
\text { IN ..., * OF ..., * } \\
\text { WITH ..., * TO ..., } \\
\text { improve * } \\
\text { manufacturing: * } \\
\text { process, * design }\end{array}$ & $\begin{array}{l}\text { Almannai et al. (2008), Arcidiacono } \\
\text { and Campatelli (2004), Bertelli and } \\
\text { Loureiro (2015), Bowles and Pelaez } \\
\text { (1995), Braglia et al. (2007), Bell et } \\
\text { al. (1992), David et al. (2010), } \\
\text { Deshpande and Modak (2002), } \\
\text { Dominguez-Garcia et al. (2006), } \\
\text { Ebrahimipour et al. (2010), Eubanks } \\
\text { et al. (1997), Eubanks et al. (1996), } \\
\text { Hassan et al. (2010), Kim et al. } \\
\text { (2013), Kimura et al. (2002), Kmenta } \\
\text { et al. (1999), Kmenta and Ishii } \\
\text { (2000), Kmenta and Ishii (2004), } \\
\text { Kmenta et al. (2003), Ku et al. (2008), } \\
\text { Lopez et al. (2010), Mader et al. } \\
\text { (2013), Neghab et al. (2011), Wang et } \\
\text { al. (2009), Regazzoni and Russo } \\
\text { (2011), Rhee and Ishii (2003), } \\
\text { Russomanno et al. (1994), Sharma et } \\
\text { al. (2007), Sharma et al. (2005), Ming } \\
\text { Tan (2003), Tay and Lim (2010), } \\
\text { Teng and Ho (1996), Teoh and Case } \\
\text { (2004), Vahdani et al. (2015), Wang } \\
\text { (2011), Wang and Elhag (2007), } \\
\text { Wang et al. (2004), Wirawan and Ayu } \\
\text { (2014), Wirth et al. (1996), Zeng et al. } \\
\text { (2015), Zhao and Zhu (2010), Zhao et } \\
\text { al. (2009), Foster (2012) }\end{array}$ & 73 & $+1 \%$ \\
\hline
\end{tabular}


International Journal of Mathematical, Engineering and Management Sciences

Vol. 6, No. 1, 79-102, 2021

https://doi.org/10.33889/IJMEMS.2021.6.1.007

Table 6 continued ...

\begin{tabular}{|c|c|c|c|c|c|}
\hline More automation & 53 & $\begin{array}{l}\text { automate: * FMEA, * } \\
\text { XMEA, * generation, * } \\
\text { prediction, * process, * } \\
\text { mode, * OF ..., * } \\
\text { simulation, design *, } \\
\text { process *, * OF .., in } \\
\text { order to * } \\
\text { automatic: * generation, } \\
* \text { module, * extraction, * } \\
\text { validation, * way, * } \\
\text { update, * learning } \\
\text { automating: by * } \\
\text { simulate: simulate + } \\
\text { system, * in ..., * and } \\
\text { analyze, * or test, * } \\
\text { how ... }\end{array}$ & $\begin{array}{l}\text { Augustine et al. (2009), Braglia et al. } \\
\text { (2003), Carmignani (2009), Chin et } \\
\text { al. (2008), David et al. (2010), } \\
\text { Elmqvist and Nadjm-Tehreani } \\
\text { (2008), Eubanks et al. (1997), Hunt et } \\
\text { al. (1993), Kmenta et al. (2003), } \\
\text { Kmenta and Ishii (1998), Lopez et al. } \\
\text { (2010), Mader et al. (2013), Abbas } \\
\text { and Vachtsevanos (2009), } \\
\text { Montgomery and Marko (1997), } \\
\text { Montgomery et al. (1996), Ormsby et } \\
\text { al. (1991), Pelaez and Bowles (1995), } \\
\text { Palumbo (1994), Park et al. (2009), } \\
\text { Wang et al. (2009), Pillay and Wang } \\
\text { (2003), Price and Taylor (1998), Price } \\
\text { (1996), Price et al. (1995), Tay and } \\
\text { Lim (2010), Teoh and Case (2004), } \\
\text { Throop et al. (2001), Vernez et al. } \\
\text { (2004), Wang et al. (2009), Wang et } \\
\text { al. (2004), Wirth et al. (1996), Xiao et } \\
\text { al. (2011), Yang et al. (2010), Foster } \\
\text { (2012), Yasko et al. (2016) }\end{array}$ & 55 & $+4 \%$ \\
\hline Info management & 48 & $\begin{array}{l}\text { manage: * information, } \\
* \text { requirement, * } \\
\text { document, * risk, } \\
\text { sistematically } * \text {, database } \\
* \text { es, method *es, *d by } \\
\text { database, * in database } \\
\text { information: } \\
\text { maintenance *, history *, } \\
\text { diagnostic *, content } *, \\
\text { collected } * \text {, update } * * \\
\text { represents, represent } *\end{array}$ & $\begin{array}{l}\text { Bertolini et al. (2006), Bell et al. } \\
\text { (1992), Deshpande and Modak } \\
(2002) \text {, Granström (2008), Kmenta } \\
\text { and Ishii (2004), Kumar and } \\
\text { Chaturvedhi (2011), Liu et al. (2010), } \\
\text { Pujawan and Geraldin (2009), Tay } \\
\text { and Lim (2010), Teng and Ho (1996), } \\
\text { Wirawan and Ayu (2014), Yang et al. } \\
\text { (2010) }\end{array}$ & 49 & $+2 \%$ \\
\hline Guidelines & 40 & $\begin{array}{l}\text { guidelines: design *, } \\
\text { methodological } *, \\
\text { include } *, * \text { are ..., } * \\
\text { for ..., ... as } * \\
\text { through: } * \text { guidelines }\end{array}$ & $\begin{array}{l}\text { Arcidiacono and Campatelli (2004), } \\
\text { Bevilacqua et al. (2000), Braglia et al. } \\
\text { (2003), David et al. (2010), Hassan et } \\
\text { al. (2010), Kara-Zaitri et al. (1991), } \\
\text { Mandal and Maiti (2014), Neghab et } \\
\text { al. (2011), Niu et al. (2011), Petrovic } \\
\text { et al. (2014), Wang et al. (2009), } \\
\text { Shahin (2004), Tay and Lim (2010), } \\
\text { Wang and Elhag (2007), Wang et al. } \\
\text { (2009), Wang et al. (2004), Wardani } \\
\text { and Pharmatrisanti (2011), Wirth et } \\
\text { al. (1996), Zafiropoulos and Dyalinas } \\
\text { (2005) }\end{array}$ & 31 & $-22 \%$ \\
\hline Complex systems & 21 & complex: $*$ system & $\begin{array}{l}\text { Bevilacqua et al. (2000), Braglia et al. } \\
\text { (2003), David et al. (2010), } \\
\text { Dominguez-Garcia et al. (2006), } \\
\text { Eubanks et al. (1997), Garcia and } \\
\text { Schirru (2005), Liu et al. (2012), Liu } \\
\text { et al. (2010), Mader et al. (2013), } \\
\text { Rhee and Ishii (2003), Sharma and } \\
\text { Sharma (2010), Sharma et al. (2008), } \\
\text { Vernez et al. (2004), Xiao et al. } \\
(2011)\end{array}$ & 35 & $+67 \%$ \\
\hline User Interface & 19 & $\begin{array}{l}\text { through: } * \text { user interface } \\
\text { user: } * \text { interface }\end{array}$ & $\begin{array}{l}\text { Chin et al. (2008), Hassan et al. } \\
(2010) \text {, Al-Humaidi and Tan (2012) }\end{array}$ & 21 & $+11 \%$ \\
\hline New criteria & 5 & $\begin{array}{l}\text { reduce: } * \text { number, } * \text { the } \\
\text { amount of information }\end{array}$ & Catelani et al. (2015) & 3 & $-40 \%$ \\
\hline
\end{tabular}


International Journal of Mathematical, Engineering and Management Sciences

Vol. 6, No. 1, 79-102, 2021

https://doi.org/10.33889/IJMEMS.2021.6.1.007

Table 6 continued ...

\begin{tabular}{|c|c|c|c|c|c|}
\hline $\begin{array}{l}\text { New methods for } \\
\text { Failure Modes }\end{array}$ & 65 & $\begin{array}{l}\text { mode: determine *, } \\
\text { failure * entry, potential } \\
\text { failure * } \\
\text { identify: identify * }\end{array}$ & $\begin{array}{l}\text { Bertolini et al. (2006), Bell et al. } \\
\text { (1992), Chang and Wen (2010), } \\
\text { Dominguez-Garcia et al. (2006), } \\
\text { Eubanks et al. (1997), Garcia and } \\
\text { Gilabert (2011), Garcia and Schirru } \\
\text { (2005), Goble and Brombacher } \\
\text { (1999), Hassan et al. (2010), Jee et al. } \\
\text { (2015), Jeon et al. (2007), Jong et al. } \\
\text { (2013), Kmenta and Ishii (2000), } \\
\text { Kmenta and Ishii (1998), Ku et al. } \\
\text { (2008), Kutlu and Ekmekcioglu } \\
\text { (2012), Liu et al. (2010), Liu et al. } \\
\text { (2014), Liu et al. (2011), Lopez et al. } \\
\text { (2010), Mader et al. (2013), Mathew } \\
\text { et al. (2012), Montgomery and Marko } \\
\text { (1997), Montgomery et al. (1996), } \\
\text { Pillay and Wang (2003), Regazzoni } \\
\text { and Russo (2011), Rhee and Ishii } \\
\text { (2003), Sharma and Sharma (2010), } \\
\text { Sharma et al. (2008), Ming Tan } \\
\text { (2003), Teng and Ho (1996), Al- } \\
\text { Humaidi and Tan (2012), Vahdani et } \\
\text { al. (2015), Zafiropoulos and Dyalinas } \\
\text { (2005), Tingdi et al. (2004), Foster } \\
\text { (2012), Abdelgawad and Fayek } \\
\text { (2010) }\end{array}$ & 67 & $+3 \%$ \\
\hline $\begin{array}{l}\text { New methods for } \\
\text { Failure Effects }\end{array}$ & 43 & $\begin{array}{l}\text { effect: identify } * \\
\text { determine: } * \text { effects } \\
\text { identify: } * \text { effects } \\
\text { define: } * \text { effects }\end{array}$ & $\begin{array}{l}\text { Bas (2011), Braglia et al. (2007), } \\
\text { Braglia et al. (2003), Elmqvist and } \\
\text { Nadjm-Tehreani (2008), Eubanks et } \\
\text { al. (1997), Eubanks et al. (1996), } \\
\text { Gandhi and Agrawal (1992), Jee et al. } \\
\text { (2015), Kimura et al. (2002), Kmenta } \\
\text { and Ishii (2000), Liu et al. (2014), Liu } \\
\text { et al. (2011), Lopez et al. (2010), } \\
\text { Abbas and Vachtsevanos (2009), } \\
\text { Neghab et al. (2011), Ozarin (2008), } \\
\text { Pelaez and Bowles (1995), } \\
\text { Regazzoni and Russo (2011), Sharma } \\
\text { et al. (2008), Suddle (2009), Teng and } \\
\text { Ho (1996), Vahdani et al. (2015), } \\
\text { Wang et al. (2009), Wirth et al. } \\
\text { (1996), Yang et al. (2010), } \\
\text { Zafiropoulos and Dyalinas (2005), } \\
\text { Zhou et al. (2012) }\end{array}$ & 45 & $+5 \%$ \\
\hline $\begin{array}{l}\text { Combine multiple } \\
\text { Failures Effects }\end{array}$ & 26 & $\begin{array}{l}\text { effect: * relationship, * } \\
\text { combination } \\
\text { multiple: * failures, * } \\
\text { effects, * fault, * } \\
\text { propagation, * failure } \\
\text { scenario } \\
\text { combination: failure *, } \\
\text { cause and effect *, } \\
\text { possible * }\end{array}$ & $\begin{array}{l}\text { David et al. (2010), Kmenta and Ishii } \\
\text { (2004), Ku et al. (2008), Liu et al. } \\
\text { (2010), Lopez et al. (2010), Palumbo } \\
\text { (1994), Price and Taylor (1998), Rhee } \\
\text { and Ishii (2002), Rhee and Ishii } \\
\text { (2003), Seyed-Hosseini et al. (2006), } \\
\text { Suddle (2009), Thurnes et al. (2015), } \\
\text { Xiao et al. (2011) }\end{array}$ & 27 & $+4 \%$ \\
\hline $\begin{array}{l}\text { New methods for } \\
\text { Failure Causes }\end{array}$ & 15 & $\begin{array}{l}\text { identify: } * \text { mode, } * \\
\text { cause } \\
\text { find: } * \text { cause }\end{array}$ & $\begin{array}{l}\text { Augustine et al. (2009), Denson et al. } \\
\text { (2014), Jee et al. (2015), Kara-Zaitri } \\
\text { et al. (1991), Kmenta et al. (1999), } \\
\text { Kmenta and Ishii (2000), Kmenta and } \\
\text { Ishii (2004), Kmenta and Ishii (1998), } \\
\text { Ku et al. (2008), Kumar and } \\
\text { Chaturvedhy (2011), Laaroussi et al. } \\
\text { (2007), Regazzoni and Russo (2011), } \\
\text { Sharma et al. (2008), Yadav et al. } \\
\text { (2006) }\end{array}$ & 20 & $+33 \%$ \\
\hline
\end{tabular}


International Journal of Mathematical, Engineering and Management Sciences

Vol. 6, No. 1, 79-102, 2021

https://doi.org/10.33889/IJMEMS.2021.6.1.007

Table 6 continued ...

\begin{tabular}{|c|c|c|c|c|c|}
\hline Statistical methods & 78 & $\begin{array}{l}\text { } \\
\text { statistic: * risk, * fault, * } \\
\text { class } \\
\text { probability: occurrence } \\
* \text {, failure *, severity *, } \\
\text { fuzzy }{ }^{*} \text { value, estimate } \\
* \text {, conditional } * \\
\text { estimated } * \\
\text { evaluate risk with: } * \\
\text { risk with fuzzy } \\
* \text { risk of: * risk of fuzzy } \\
\text { asses: } * \text { probability } \\
\text { determine: * probability } \\
\text { estimate: * probability } \\
\text { compute: * probability } \\
\text { associate: * probability } \\
\text { evaluate: * probability } \\
\text { through: * probability }\end{array}$ & $\begin{array}{l}\text { Bas (2011), Bevilacqua et al. (2000), } \\
\text { Bowles and Pelaez (1995), Chin et al. } \\
\text { (2008), David et al. (2010), } \\
\text { Dominguez-Garcia et al. (2006), Van } \\
\text { Bossuyt et al. (2012), Elmqvist and } \\
\text { Nadjm-Tehreani (2008), Garcia and } \\
\text { Gilabert (2011), Garcia and Schirru } \\
\text { (2005), Jenab et al. (2015), Kerk et al. } \\
\text { (2017), Kim et al. (2013), Kmenta } \\
\text { and Ishii (2000), Kmenta and Ishii } \\
\text { (2004), Kmenta et al. (2003), Kmenta } \\
\text { and Ishii (1998), Ku et al. (2008), } \\
\text { Kumar and Chaturvedhy (2011), Lee } \\
\text { (2001b), Liu et al. (2011), Liu et al. } \\
\text { (2010), Mandal and Maiti (2014), } \\
\text { Mandal et al. (2015), Niu et al. } \\
\text { (2011), Pillay and Wang (2002), } \\
\text { Pillay and Wang (2003), Pujawan and } \\
\text { Geraldin (2009), Sharma and Sharma } \\
\text { (2010), Sharma et al. (2008), Sharma } \\
\text { et al. (2007), Sharma et al. (2005), } \\
\text { Suddle (2009), Suganthi and Kumar } \\
\text { (2010), Tang et al. (2015), Thurnes et } \\
\text { al. (2015), Vahdani et al. (2015), } \\
\text { Wang et al. (2004), Xiao et al. (2011), } \\
\text { Yang et al. (2010), Zafiropoulos and } \\
\text { Dyalinas (2005), Yang et al. (2009), } \\
\text { Zambrano et al. (2007), Foster (2012) } \\
\end{array}$ & 80 & $+3 \%$ \\
\hline $\begin{array}{l}\text { Requirements- } \\
\text { based criteria }\end{array}$ & 31 & $\begin{array}{l}\text { requirement: } * \text { is ..., } \\
\text { is not ..., } * \text { is feedback, } \\
\text { verify } *, \text { maintain } *, \\
\text { enhance } * \text {, meeting } \\
\text { reliability } * \text {, reliability } * \\
\text { analysis, * associated } \\
\text { with ... }\end{array}$ & $\begin{array}{l}\text { David et al. (2010), Mader et al. } \\
\text { (2013), Teng and Ho (1996), Wang } \\
\text { and Elhag (2007), Yadav et al. } \\
(2006) \text {, Zafiropoulos and Dyalinas } \\
(2005)\end{array}$ & 24 & $-23 \%$ \\
\hline Economic criteria & 16 & $\begin{array}{l}\text { evaluate risk in: } * \text { risk } \\
\text { in economic terms } \\
\text { risk: cost } * \text {, cost } * \\
\text { evaluation, monetary } * \\
\text { evaluation, measure * in } \\
\text { term of, business } * \text {, } \\
\text { economical * } \\
\text { determine: } * \text { financial } \\
\text { risk } \\
\text { cost: evaluation * } \\
\text { through: } * \text { economic } \\
\text { criteria } \\
\text { economic: } * \\
\text { consideration, } * \text { decision } \\
\text { making }\end{array}$ & $\begin{array}{l}\text { Braglia et al. (2003), Carmignani } \\
\text { (2009), Van Bossuyt et al. (2012), } \\
\text { Hassan et al. (2010), Kmenta and Ishii } \\
\text { (2000), Rhee and Ishii (2002), Rhee } \\
\text { and Ishii (2003), Sharma and Sharma } \\
\text { (2010), Sharma et al. (2008), Su et al. } \\
\text { (2014), Suddle (2009) }\end{array}$ & 17 & $+6 \%$ \\
\hline Historical data & 14 & historical: $*$ datum & $\begin{array}{l}\text { Chang and Wen (2010), Kimura et al. } \\
\text { (2002), Liu et al. (2011), Liu et al. } \\
\text { (2012), Lopez et al. (2010), Petrovic } \\
\text { et al. (2014), Regazzoni and Russo } \\
\text { (2011), Tay and Lim (2010), Teoh } \\
\text { and Case (2004), Vahdani et al. } \\
(2015) \text {, Abdelgawad and Fayek } \\
(2010)\end{array}$ & 27 & $+93 \%$ \\
\hline
\end{tabular}


International Journal of Mathematical, Engineering and Management Sciences

Vol. 6, No. 1, 79-102, 2021

https://doi.org/10.33889/IJMEMS.2021.6.1.007

Table 6 continued ...

\begin{tabular}{|c|c|c|c|c|c|}
\hline Qualitative criteria & 5 & $\begin{array}{l}\text { risk: qualitative } * \\
\text { evaluation } \\
\text { qualitative: * analysis, * } \\
\text { evaluation, * assessment }\end{array}$ & $\begin{array}{l}\text { Bowles and Pelaez (1995), Braglia et } \\
\text { al. (2007), Chin et al. (2008), } \\
\text { Demichela et al. (2004), Dominguez- } \\
\text { Garcia et al. (2006), Kim et al. (2013), } \\
\text { Sharma et al. (2008), Zafiropoulos } \\
\text { and Dyalinas (2005), Abdelgawad } \\
\text { and Fayek (2010) }\end{array}$ & 13 & $+160 \%$ \\
\hline $\begin{array}{l}\text { Results } \\
\text { representation }\end{array}$ & 34 & $\begin{array}{l}\text { result: represent *, } \\
\text { present * } \\
\text { representation: provide } \\
* \\
\text { by: * providing results } \\
\text { representation }\end{array}$ & $\begin{array}{l}\text { Bas (2011), Carmignani (2009), Chai } \\
\text { et al. (2016), Chang and Wen (2010), } \\
\text { Kmenta and Ishii (2004), Kumar and } \\
\text { Chaturvedhy (2011), Kutlu and } \\
\text { Ekmekcioglu (2011), Lindahl (1999), } \\
\text { Liu et al. (2010), Mandal and Maiti } \\
\text { (2014), Mandal et al. (2015), Petrovic } \\
\text { et al. (2014), Seyed-Hosseini et al. } \\
\text { (2006), Sharma et al. (2005), Zhao } \\
\text { and Zhu (2010) }\end{array}$ & 37 & $+9 \%$ \\
\hline New methods & 29 & $\begin{array}{l}\text { integrate: } * \text { technique, } * \\
\text { tool, * method, } * \\
\text { problem, } * \text { with ... }\end{array}$ & $\begin{array}{l}\text { Arcidiacono and Campatelli (2004), } \\
\text { Braglia (2000), Braglia et al. (2007), } \\
\text { David et al. (2010), Elmqvist and } \\
\text { Nadjm-Tehreani (2008), Hu et al. } \\
\text { (2014), Kutlu and Ekmekcioglu } \\
\text { (2011), Laaroussi et al. (2007), Lee } \\
\text { (2001b), Lolli et al. (2015), Neghab et } \\
\text { al. (2011), Regazzoni and Russo } \\
\text { (2011), Thurnes et al. (2015), Yang et } \\
\text { al. (2010), Yu et al. (2011), } \\
\text { Zafiropoulos and Dyalinas (2005), } \\
\text { Emovon et al. (2014) }\end{array}$ & 32 & $+10 \%$ \\
\hline $\begin{array}{l}\text { Use FMEA for } \\
\text { other purposes }\end{array}$ & 8 & $\begin{array}{l}\text { use: * FMEA for } \ldots \\
\text { apply: * FMEA for } \ldots\end{array}$ & $\begin{array}{l}\text { Chin et al. (2008), Kerk et al. (2017), } \\
\text { Kmenta et al. (1999), Kmenta and } \\
\text { Ishii (2004), Zhou et al. (2012) }\end{array}$ & 12 & $+50 \%$ \\
\hline
\end{tabular}

\subsection{Discussion of the Results}

Both the tests achieved positive results by confirming the validity of the proposed methodology both in identifying the features and in classifying the documents according to them.

During the first test, all the features of the previous survey have been identified by using simple generic keywords not requiring a specific knowledge about FMEA. While, the results arising from the second test are encouraging even if with different levels of efficacy of the queries depending on the cases: for some of them (e.g. Historical data) the keyword "Historical" in relation to the word "Datum" has been sufficient to determine many more documents compared to the previous survey $(+93 \%)$, while in other cases (e.g. Economic Criteria) we did not obtain the same success.

Only for specific searches, the knowledge about FMEA had been required: e.g. to collect all the documents dealing with FMEA anticipation, the network of relations generated from the more obvious keyword (i.e. "Anticipate") has not been sufficient, so we had also to use the keywords "Design" and "Manufacturing" which represent the two main phases during which FMEA can be anticipated. This strategy can be considered for searching the more abstract features underlying a wider interpretation and expressed through different textual forms; e.g. to identify the documents dealing with the integrations with "Statistical methods", the keyword "probability" proved to be much more useful than the more obvious "statistic". Consequently, the choice of the most suitable features of analysis can influence the efficacy of the proposed methodology: the "better ones" are able to easily suggest a great number of possible lexical declinations to be used as keywords to increase the recall of the results. 
International Journal of Mathematical, Engineering and Management Sciences

Vol. 6, No. 1, 79-102, 2021

https://doi.org/10.33889/IJMEMS.2021.6.1.007

A disadvantage of the proposed methodology regards the electronic format of the analyzed inputs, which are limited to the pure textual information, by excluding other contents (e.g. images, graphs and tables). As consequence, through the experiments emerged that some information can be lost, and this aspect is more accentuated in papers rather than in patents, which authors are generally used to more accurately describe the content of not-textual elements within the text.

Anyway, the undoubted advantage of the methodology is the strong reduction of the time required to perform the analysis, quantifiable in the executed tests in 5 days instead of in more than 6 weeks for the manual analysis.

Among the expected future developments there are the automation of the definition of the electronic pool and the research for the integrations with tools for the management of the bibliography (e.g. Scopus and Mendeley).

\section{Conclusions}

In this paper, a semi-automatic methodology to build FMEA surveys involving a home-built syntactic Parser has been introduced and the results of its test on a pool of 286 documents, divided between 177 and 109 patents, replying a previous manual work of analysis, have been reported.

As result from the tests, the proposed methodology proved to be useful both to automatically determine the main features of interest to be analyzed within the pool and to classify the documents according to them, while saving a consistent amount of time.

Furthermore, the qualitative level achieved by the analysis (recall) can be in most cases higher than that manually obtained even if the knowledge about FMEA of the executioner can be crucial especially for checking possible misunderstanding related to the specific jargon. However, this fact seems do not preclude novices from using the methodology by reaching good results.

In particular, the use of the methodology to identify new features can increase the depth of the level of the analysis also in addition to those manually pre-determined for particular exigencies. While, the automatic classify the documents can be instead a useful tool especially for not expert users, since the major part of the results (> 60\%) has been achieved by using generic and easy conceivable keywords, even if a supervised selection of homogenous and alternative features for the analysis can increase the precision of the analysis.

\section{Conflict of Interest}

The authors confirm that there is no conflict of interest to declare for this publication.

\section{Acknowledgments}

This research did not receive any specific grant from funding agencies in the public, commercial, or not-for-profit sectors. The authors sincerely appreciate the editor and reviewers for their time and valuable comments.

\section{References}

Abbas, M., \& Vachtsevanos, G.J. (2009, September). A system-level approach to fault progression analysis in complex engineering systems. In the Annual Conference of the Prognostics and Health Management Society, (pp. 1-7). San Diego, USA. 
International Journal of Mathematical, Engineering and Management Sciences

Vol. 6, No. 1, 79-102, 2021

https://doi.org/10.33889/IJMEMS.2021.6.1.007

Abdelgawad, M., \& Fayek, A.R. (2010). Risk management in the construction industry using combined fuzzy FMEA and fuzzy AHP. Journal of Construction Engineering and Management, 136(9), 1028-1036.

Al-Humaidi, H.M., \& Tan, F.H. (2012). Using fuzzy failure mode effect analysis to model cave-in accidents. Journal of Performance of Constructed Facilities, 26(5), 702-719.

Almannai, B., Greenough, R., \& Kay, J. (2008). A decision support tool based on QFD and FMEA for the selection of manufacturing automation technologies. Robotics and Computer-Integrated Manufacturing, 24(4), 501-507.

Arcidiacono, G., \& Campatelli, G. (2004). Reliability improvement of a diesel engine using the FMETA approach. Quality and Reliability Engineering International, 20(2), 143-154.

Augustine, M., Yadav, O.P., Jain, R., \& Rathore, A. (2009, December). Modeling physical systems for failure analysis with rate cognitive maps. In 2009 IEEE International Conference on Industrial Engineering and Engineering Management (pp. 1758-1762). IEEE. Hong Kong, China.

Bas, E. (2011). An investment plan for preventing child injuries using risk priority number of failure mode and effects analysis methodology and a multi-objective, multi-dimensional mixed 0-1 knapsack model. Reliability Engineering \& System Safety, 96(7), 748-756.

Bell, D., Cox, L., Jackson, S., \& Schaefer, P. (1992, January). Using causal reasoning for automated failure modes and effects analysis (FMEA). In Annual Reliability and Maintainability Symposium 1992 Proceedings (pp. 343-353). IEEE. Las Vegas, USA.

Bertelli, C.R., \& Loureiro, G. (2015). Quality problems in complex systems even considering the application of quality initiatives during product development. In ISPE CE, (pp. 40-51). Delft, Netherlands.

Bertolini, M., Bevilacqua, M., \& Massini, R. (2006). FMECA approach to product traceability in the food industry. Food Control, 17(2), 137-145.

Bevilacqua, M., Braglia, M., \& Gabbrielli, R. (2000). Monte Carlo simulation approach for a modified FMECA in a power plant. Quality and Reliability Engineering International, 16(4), 313-324.

Boggarapu, V., Krishnaswamy, M.S., Pothakamuri, S. (2001). Large-scale comprehensive real-time monitoring framework for industrial facilities. U.S. Patent No. 13,113,593. Washington, DC: U.S. Patent and Trademark Office.

Bouti, A., \& Kadi, D.A. (1994). A state-of-the-art review of FMEA/FMECA. International Journal of Reliability, Quality and Safety Engineering, 1(4), 515-543.

Bowles, J.B., \& Peláez, C.E. (1995). Fuzzy logic prioritization of failures in a system failure mode, effects and criticality analysis. Reliability Engineering \& System Safety, 50(2), 203-213.

Braglia, M. (2000). MAFMA: multi-attribute failure mode analysis. International Journal of Quality \& Reliability Management, 17(9), 1017-1033.

Braglia, M., Fantoni, G., \& Frosolini, M. (2007). The house of reliability. International Journal of Quality \& Reliability Management, 24(4), 420-440.

Braglia, M., Frosolini, M., \& Montanari, R. (2003). Fuzzy TOPSIS approach for failure mode, effects and criticality analysis. Quality and Reliability Engineering International, 19(5), 425-443.

Carmignani, G. (2009). An integrated structural framework to cost-based FMECA: the priority-cost FMECA. Reliability Engineering \& System Safety, 94(4), 861-871.

Catelani, M., Ciani, L., Cristaldi, L., Faifer, M., Lazzaroni, M., \& Khalil, M. (2015, May). Toward a new definition of FMECA approach. In 2015 IEEE International Instrumentation and Measurement Technology Conference (I2MTC) Proceedings (pp. 981-986). IEEE. Pisa, Italy. 
International Journal of Mathematical, Engineering and Management Sciences

Vol. 6, No. 1, 79-102, 2021

https://doi.org/10.33889/IJMEMS.2021.6.1.007

Chai, K.C., Jong, C.H., Tay, K.M., \& Lim, C.P. (2016). A perceptual computing-based method to prioritize failure modes in failure mode and effect analysis and its application to edible bird nest farming. Applied Soft Computing, 49, 734-747.

Chang, K.H., \& Wen, T.C. (2010). A novel efficient approach for DFMEA combining 2-tuple and the OWA operator. Expert Systems with Applications, 37(3), 2362-2370.

Chen, Y., Gao, L., Kang, R., \& Zhang, X. (2013). Newly-developed aviation electronic product hardware comprehensive FMECA method. Chinese patent No. CN 10632162 (A). National Intellectual Property Administration.

Chin, K.S., Chan, A., \& Yang, J.B. (2008). Development of a fuzzy FMEA based product design system. The International Journal of Advanced Manufacturing Technology, 36(7-8), 633-649.

Conchieri, J.A., Dell'anno, M.J., Hardwicke, E., \& Wiederhold, R.P. (2009). Systems and methods for analyzing failure modes according to cost. U.S. Patent No. 11,859,199. Washington, DC: U.S. Patent and Trademark Office.

Cutuli, G., Imperiale, F., Lissoni, R., Marchese, M. (2001). Design failure mode effect analysis (DFMEA). U.S. Patent No. 10,330,485. Washington, DC: U.S. Patent and Trademark Office.

Dale, B.G., \& Shaw, P. (1990). Failure mode and effects analysis in the UK motor industry: a state-of-theart study. Quality and Reliability Engineering International, 6(3), 179-188.

David, P., Idasiak, V., \& Kratz, F. (2010). Reliability study of complex physical systems using SysML. Reliability Engineering \& System Safety, 95(4), 431-450.

Demichela, M., Piccinini, N., Ciarambino, I., \& Contini, S. (2004). How to avoid the generation of logic loops in the construction of fault trees. Reliability Engineering \& System Safety, 84(2), 197-207.

Denson, B., Tang, S.Y., Gerber, K., \& Blaignan, V. (2014, January). An effective and systematic design FMEA approach. In 2014 Reliability and Maintainability Symposium (pp. 1-6). IEEE. Colorado Springs, USA.

Deshpande, V.S., \& Modak, J.P. (2002). Application of RCM to a medium scale industry. Reliability Engineering \& System Safety, 77(1), 31-43.

Dominguez-Garcia, A.D., Kassakian, J.G., \& Schindall, J.E. (2006). Reliability evaluation of the power supply of an electrical power net for safety-relevant applications. Reliability Engineering \& System Safety, 91(5), 505-514.

Ebrahimipour, V., Rezaie, K., \& Shokravi, S. (2010). An ontology approach to support FMEA studies. Expert Systems with Applications, 37(1), 671-677.

Elmqvist, J., \& Nadjm-Tehrani, S. (2008, March). Tool support for incremental failure mode and effects analysis of component-based systems. In Proceedings of the Conference on Design, Automation and Test in Europe, (pp. 921-927). Dresden, Germany.

Emovon, I., Norman, R.A., \& Murphy, A.J. (2014, June). A new tool for prioritising the risk of failure modes for marine machinery systems. In ASME 2014 33rd International Conference on Ocean, Offshore and Arctic Engineering. American Society of Mechanical Engineers, (pp. 1-10). San Francisco, USA.

Eubanks, C.F., Kmenta, S., \& Ishii, K. (1996, September). System behavior modeling as a basis for advanced failure modes and effects analysis. In. Proceedings of the 1996 ASME Design Engineering Technical Conferences and Computers in Engineering Conference (pp. 1-8). Irvine, California.

Eubanks, C.F., Kmenta, S., \& Ishii, K. (1997, September). Advanced failure modes and effects analysis using behavior modeling. In ASME Design Engineering Technical Conferences, (pp. 14-17). Sacramento, USA. 
International Journal of Mathematical, Engineering and Management Sciences

Vol. 6, No. 1, 79-102, 2021

https://doi.org/10.33889/IJMEMS.2021.6.1.007

Foster, C.R. (2012, August). Improving failure mode and effects analysis as a cognitive simulation. In ASME 2012 International Design Engineering Technical Conferences and Computers and Information in Engineering Conference (pp. 719-726). Chicago, USA.

Gandhi, O.P., \& Agrawal, V.P. (1992). FMEA - A diagraph and matrix approach. Reliability Engineering \& System Safety, 35(2), 147-158.

Garcia, A., \& Gilabert, E. (2011). Mapping FMEA into Bayesian networks. International Journal of Performability Engineering, 7(6), 525-537.

Garcia, P.A., \& Schirru, R. (2005). A fuzzy data envelopment analysis approach for FMEA. Progress in Nuclear Energy, 46(3-4), 359-373.

Goble, W.M., \& Brombacher, A.C. (1999). Using a failure modes, effects and diagnostic analysis (FMEDA) to measure diagnostic coverage in programmable electronic systems. Reliability Engineering \& System Safety, 66(2), 145-148.

Granström, R. (2008). A system and stakeholder approach for the identification of condition information: a case study for the Swedish railway. Proceedings of the Institution of Mechanical Engineers, Part F: Journal of Rail and Rapid Transit, 222(4), 399-412.

Guo, Z., \& Liggesmeyer, P. (2013). Apparatus, method, and computer program product for scenario-based identification of complete safety-based requirements specification. U.S. Patent No. 13,181,681. Washington, DC: U.S. Patent and Trademark Office.

Hassan, A., Siadat, A., Dantan, J.Y., \& Martin, P. (2010). Conceptual process planning-an improvement approach using QFD, FMEA, and ABC methods. Robotics and Computer-Integrated Manufacturing, 26(4), 392-401.

Hu, C.M., Lin, C.A., Chang, C.H., Cheng, Y.J., \& Tseng, P.Y. (2014). Integration with QFDs, TRIZ and FMEA for control valve design. In Zhang, H., Han, M., \& Zhao, X.J. (eds) Advanced Materials Research (Vol. 1021, pp. 167-180). Trans Tech Publications Ltd.

Hunt, J.E., Price, C.J., \& Lee, M.H. (1993). Automating the FMEA process. Intelligent Systems Engineering, 2(2), 119-132.

Jee, T.L., Tay, K.M., \& Lim, C.P. (2015). A new two-stage fuzzy inference system-based approach to prioritize failures in failure mode and effect analysis. IEEE Transactions on Reliability, 64(3), 869-877.

Jenab, K., Khoury, S., \& Rodriguez, S. (2015). Effective FMEA analysis or not. Strategic Management Quarterly, 3(2), 25-36.

Jeon, J., Hyland, S., Burns, C.M., \& Momtahan, K. (2007, October). Challenges with applying FMEA to the process for reading labels on injectable drug containers. In Proceedings of the Human Factors and Ergonomics Society Annual Meeting (Vol. 51, No. 11, pp. 735-739). Sage CA: Los Angeles, CA: SAGE Publications.

Jong, C.H., Tay, K.M., \& Lim, C.P. (2013). Application of the fuzzy failure mode and effect analysis methodology to edible bird nest processing. Computers and Electronics in Agriculture, 96, 90-108.

Kara-Zaitri, C., Keller, A.Z., Barody, I., \& Fleming, P.V. (1991, January). An improved FMEA methodology. In Annual Reliability and Maintainability Symposium. 1991 Proceedings (pp. 248-252). IEEE. Orlando, USA.

Kerk, Y.W., Tay, K.M., \& Lim, C.P. (2017). An analytical interval fuzzy inference system for risk evaluation and prioritization in failure mode and effect analysis. IEEE Systems Journal, 11(3), 1589-1600.

Kim, K.O., Yang, Y., \& Zuo, M.J. (2013). A new reliability allocation weight for reducing the occurrence of severe failure effects. Reliability Engineering \& System Safety, 117, 81-88. 
International Journal of Mathematical, Engineering and Management Sciences

Vol. 6, No. 1, 79-102, 2021

https://doi.org/10.33889/IJMEMS.2021.6.1.007

Kimura, F., Hata, T., \& Kobayashi, N. (2002, May). Reliability-centered maintenance planning based on computer-aided FMEA. In Processing of the 35th CIRP-International Seminar on Manufacturing Systems (pp. 506-511). Seoul, Korea.

Kmenta, S., \& Ishii, K. (1998). Advanced FMEA using meta behavior modeling for concurrent design of products and controls. In Proceedings of the 1998 ASME Design Engineering Technical Conferences, (pp. 1-9). Atlanta, USA.

Kmenta, S., \& Ishii, K. (2000). Scenario-based FMEA: a life cycle cost perspective. In Processing of ASME Design Engineering Technical Conference, (pp. 1-11). Baltimore, USA.

Kmenta, S., \& Ishii, K. (2004). Scenario-based failure modes and effects analysis using expected cost. Journal of Mechanical Design, 126(6), 1027-1035.

Kmenta, S., Cheldelin, B., \& Ishii, K. (2003, January). Assembly FMEA: a simplified method for identifying assembly errors. In ASME 2003 International Mechanical Engineering Congress and Exposition (pp. 315-323). American Society of Mechanical Engineers Digital Collection. Washington, USA.

Kmenta, S., Fitch, P., \& Ishii, K. (1999). Advanced failure modes and effects analysis of complex processes. In Proceedings of the 1999 ASME Design Engineering Technical Conference, Design for Manufacturing Conference, (pp. 267-276). Las Vegas, USA.

Ku, C., Chen, Y.S., \& Chung, Y.K. (2008, September). An intelligent FMEA system implemented with a hierarchy of back-propagation neural networks. In 2008 IEEE Conference on Cybernetics and Intelligent Systems (pp. 203-208). IEEE. Chengdu, China.

Kumar, E.V., \& Chaturvedi, S.K. (2011). Prioritization of maintenance tasks on industrial equipment for reliability: a fuzzy approach. International Journal of Quality \& Reliability Management, 28(1), 109126.

Kutlu, A.C., \& Ekmekçioğlu, M. (2012). Fuzzy failure modes and effects analysis by using fuzzy TOPSISbased fuzzy AHP. Expert Systems with Applications, 39(1), 61-67.

Laaroussi, A., Fiès, B., Vankeisbelckt, R., \& Hans, J. (2007). Ontology-aided FMEA for construction products. In Bringing ITC knowledge to work, 24th W78 Conference, (pp. 189-194). Maribor, Slovenia.

Lee, B.H. (2001a). Using FMEA models and ontologies to build diagnostic models. AIEDAM, 15(4), 281293.

Lee, B.H. (2001b). Using Bayes belief networks in industrial FMEA modeling and analysis. In Annual Reliability and Maintainability Symposium. 2001 Proceedings. International Symposium on Product Quality and Integrity (Cat. No. 01CH37179) (pp. 7-15). IEEE. Philadelphia, USA.

Lindahl, M. (1999, February). E-FMEA-a new promising tool for efficient design for environment. In Proceedings First International Symposium on Environmentally Conscious Design and Inverse Manufacturing (pp. 734-739). IEEE. Tokyo, Japan.

Liu, H.C., Liu, L., \& Liu, N. (2013). Risk evaluation approaches in failure mode and effects analysis: A literature review. Expert Systems with Applications, 40(2), 828-838.

Liu, H.C., Liu, L., Bian, Q.H., Lin, Q.L., Dong, N., \& Xu, P.C. (2011). Failure mode and effects analysis using fuzzy evidential reasoning approach and grey theory. Expert Systems with Applications, 38(4), 4403-4415.

Liu, H.C., Liu, L., Liu, N., \& Mao, L.X. (2012). Risk evaluation in failure mode and effects analysis with extended VIKOR method under fuzzy environment. Expert Systems with Applications, 39(17), 1292612934.

Liu, H.C., You, J.X., Fan, X.J., \& Lin, Q.L. (2014). Failure mode and effects analysis using D numbers and grey relational projection method. Expert Systems with Applications, 41(10), 4670-4679. 
International Journal of Mathematical, Engineering and Management Sciences

Vol. 6, No. 1, 79-102, 2021

https://doi.org/10.33889/IJMEMS.2021.6.1.007

Liu, J., Martínez, L., Wang, H., Rodríguez, R.M., \& Novozhilov, V. (2010). Computing with words in risk assessment. International Journal of Computational Intelligence Systems, 3(4), 396-419.

Lolli, F., Ishizaka, A., Gamberini, R., Rimini, B., \& Messori, M. (2015). FlowSort-GDSS-A novel group multi-criteria decision support system for sorting problems with application to FMEA. Expert Systems with Applications, 42(17-18), 6342-6349.

Lopez, F., Bartolo, C.D., Piazza, T., Passannanti, A., Gerlach, J.C., Gridelli, B., \& Triolo, F. (2010). A quality risk management model approach for cell therapy manufacturing. Risk Analysis: An International Journal, 30(12), 1857-1871.

Mader, R., Armengaud, E., Grießnig, G., Kreiner, C., Steger, C., \& Weiß, R. (2013). OASIS: An automotive analysis and safety engineering instrument. Reliability Engineering \& System Safety, 120, 150-162.

Mandal, S., \& Maiti, J. (2014). Risk analysis using FMEA: fuzzy similarity value and possibility theory based approach. Expert Systems with Applications, 41(7), 3527-3537.

Mandal, S., Singh, K., Behera, R.K., Sahu, S.K., Raj, N., \& Maiti, J. (2015). Human error identification and risk prioritization in overhead crane operations using HTA, SHERPA and fuzzy VIKOR method. Expert Systems with Applications, 42(20), 7195-7206.

Mathew, S., Alam, M., \& Pecht, M. (2012). Identification of failure mechanisms to enhance prognostic outcomes. Journal of Failure Analysis and Prevention, 12(1), 66-73.

Ming Tan, C. (2003). Customer-focused build-in reliability: a case study. International Journal of Quality \& Reliability Management, 20(3), 378-397.

Montgomery, T.A., \& Marko, K.A. (1997, January). Quantitative FMEA automation. In Annual Reliability and Maintainability Symposium (pp. 226-228). IEEE. Philadelphia, USA.

Montgomery, T.A., Pugh, D.R., Leedham, S.T., \& Twitchett, S.R. (1996, January). FMEA automation for the complete design process. In Proceedings of 1996 Annual Reliability and Maintainability Symposium (pp. 30-36). IEEE. Las Vegas, USA.

Neghab, A.P., Siadat, A., Tavakkoli-Moghaddam, R., \& Jolai, F. (2011, September). An integrated approach for risk-assessment analysis in a manufacturing process using FMEA and DES. In 2011 IEEE International Conference on Quality and Reliability (pp. 366-370). IEEE. Bangkok, Thailand.

Niu, G., Singh, S., Holland, S.W., \& Pecht, M. (2011). Health monitoring of electronic products based on Mahalanobis distance and Weibull decision metrics. Microelectronics Reliability, 51(2), 279-284.

Ormsby, A.R.T., Hunt, J.E., \& Lee, M.H. (1991). Towards an automated FMEA assistant. In Applications of Artificial Intelligence in Engineering VI (pp. 739-752). Springer, Dordrecht.

Ozarin, N. (2008, January). What's wrong with bent pin analysis, and what to do about it. In 2008 Annual Reliability and Maintainability Symposium (pp. 386-392). IEEE. Las Vegas, USA.

Palumbo, D. (1994, January). Automating failure modes and effects analysis. In Proceedings of Annual Reliability and Maintainability Symposium (RAMS) (pp. 304-309). IEEE. Anaheim, USA.

Park, J.H., Kim, H., \& Park, J.H. (2009, December). FMEA (Failure Mode Effect Analysis) for maintenance of mail sorting machine. In International Conference on Future Generation Communication and Networking (pp. 555-562). Springer, Berlin, Heidelberg.

Pelaez, C.E., \& Bowles, J.B. (1995, January). Applying fuzzy cognitive-maps knowledge-representation to failure modes effects analysis. In Annual Reliability and Maintainability Symposium 1995 Proceedings (pp. 450-456). IEEE. Washington, USA.

Petrović, D.V., Tanasijević, M., Milić, V., Lilić, N., Stojadinović, S., \& Svrkota, I. (2014). Risk assessment model of mining equipment failure based on fuzzy logic. Expert Systems with Applications, 41(18), 8157-8164. 
International Journal of Mathematical, Engineering and Management Sciences

Vol. 6, No. 1, 79-102, 2021

https://doi.org/10.33889/IJMEMS.2021.6.1.007

Pickard, K., Muller, P., \& Bertsche, B. (2005, January). Multiple failure mode and effects analysis-an approach to risk assessment of multiple failures with FMEA. In Annual Reliability and Maintainability Symposium, 2005 Proceedings (pp. 457-462). IEEE. Alexandria, USA.

Pillay, A., \& Wang, J. (2002). Risk assessment of fishing vessels using fuzzy set approach. International Journal of Reliability, Quality and Safety Engineering, 9(02), 163-181.

Pillay, A., \& Wang, J. (2003). Modified failure mode and effects analysis using approximate reasoning. Reliability Engineering \& System Safety, 79(1), 69-85.

Price, C.J. (1996, January). Effortless incremental design FMEA. In Proceedings of 1996 Annual Reliability and Maintainability Symposium (pp. 43-47). IEEE. Las Vegas, USA.

Price, C.J., \& Taylor, N.S. (1998, January). FMEA for multiple failures. In Annual Reliability and Maintainability Symposium 1998 Proceedings. International Symposium on Product Quality and Integrity (pp. 43-47). IEEE. Anaheim, USA.

Price, C.J., Pugh, D.R., Wilson, M.S., \& Snooke, N. (1995, January). The flame system: automating electrical failure mode and effects analysis (FMEA). In Annual Reliability and Maintainability Symposium 1995 Proceedings (pp. 90-95). IEEE. Washington, USA.

Pujawan, I.N., \& Geraldin, L.H. (2009). House of risk: a model for proactive supply chain risk management. Business Process Management Journal, 15(6), 953-967.

Regazzoni, D., \& Russo, D. (2011). TRIZ tools to enhance risk management. Procedia Engineering, 9, 4051.

Rhee, S.J., \& Ishii, K. (2002, January). Life cost-based FMEA incorporating data uncertainty. In ASME 2002 International Design Engineering Technical Conferences and Computers and Information in Engineering Conference (pp. 309-318). American Society of Mechanical Engineers Digital Collection. Montreal, Canada.

Rhee, S.J., \& Ishii, K. (2003). Using cost based FMEA to enhance reliability and serviceability. Advanced Engineering Informatics, 17(3-4), 179-188.

Russo, D., Fayemi, P.E., Spreafico, M., Bersano, G. (2018). Design entity recognition for bio-inspired design supervised state of the art. In: Cavallucci D., De Guio R., Koziołek S. (eds) Automated Invention for Smart Industries. TFC 2018. IFIP Advances in Information and Communication Technology, vol. 541. Springer, Cham. Pp (3-13).

Russo, D., Spreafico, C., Spreafico, M. (2019) Patent based method to evaluate the market potential of a product. In: Benmoussa, R., De Guio, R., Dubois, S., Koziołek, S. (eds) New Opportunities for Innovation Breakthroughs for Developing Countries and Emerging Economies. TFC 2019. IFIP Advances in Information and Communication Technology, vol. 572. Springer, Cham.

Russomanno, D.J., Bonnell, R.D., \& Bowles, J.B. (1994). Viewing computer-aided failure modes and effects analysis from an artificial intelligence perspective. Integrated Computer-Aided Engineering, 1(3), 209228.

Seyed-Hosseini, S.M., Safaei, N., \& Asgharpour, M.J. (2006). Reprioritization of failures in a system failure mode and effects analysis by decision making trial and evaluation laboratory technique. Reliability Engineering \& System Safety, 91(8), 872-881.

Shahin, A. (2004). Integration of FMEA and the Kano model: an exploratory examination. International Journal of Quality \& Reliability Management, 21(7), 731-746.

Sharma, R.K., \& Sharma, P. (2010). System failure behavior and maintenance decision making using, RCA, FMEA and FM. Journal of Quality in Maintenance Engineering, 16(1), 64-88. 
International Journal of Mathematical, Engineering and Management Sciences

Vol. 6, No. 1, 79-102, 2021

https://doi.org/10.33889/IJMEMS.2021.6.1.007

Sharma, R.K., Kumar, D., \& Kumar, P. (2005). Systematic failure mode effect analysis (FMEA) using fuzzy linguistic modelling. International Journal of Quality \& Reliability Management, 22(9), 986-1004.

Sharma, R.K., Kumar, D., \& Kumar, P. (2007). Modeling and analysing system failure behaviour using RCA, FMEA and NHPPP models. International Journal of Quality \& Reliability Management, 24(5), 525-546.

Sharma, R.K., Kumar, D., \& Kumar, P. (2008). Fuzzy modeling of system behavior for risk and reliability analysis. International Journal of Systems Science, 39(6), 563-581.

Spreafico, C., \& Russo, D. (2019b). Case: can triz functional analysis improve FMEA?. In: Chechurin, L., Collan, M. (eds) Advances in Systematic Creativity. Palgrave Macmillan, Cham. pp. 87-100.

Spreafico, C., \& Russo, D. (2019a). Building a semi-automatic design for reliability survey with semantic pattern recognition. In: Ram, M. (ed) Reliability Engineering: Methods and Applications, (pp. 107-126). CRC Press. Boca Raton.

Spreafico, C., Russo, D., \& Rizzi, C. (2017). A state-of-the-art review of FMEA/FMECA including patents. Computer Science Review, 25, 19-28.

Spreafico, M., Fayemi, P.E., \& Bersano, G. (2019, June). An investigation of the relations on business areas and recycled materials in circular economy. In International Conference on Sustainable Design and Manufacturing (pp. 189-199). Springer, Singapore.

Su, C.T., Lin, H.C., Teng, P.W., \& Yang, T. (2014). Improving the reliability of electronic paper display using FMEA and Taguchi methods: a case study. Microelectronics Reliability, 54(6-7), 1369-1377.

Suddle, S. (2009). The risk management of third parties during construction in multifunctional urban locations. Risk Analysis: An International Journal, 29(7), 1024-1040.

Suganthi, S., \& Kumar, D. (2010, June). FMEA without fear AND tear. In 2010 IEEE International Conference on Management of Innovation \& Technology (pp. 1118-1123). IEEE. Singapore.

Sutrisno, A., \& Lee, T.J. (2011). Service reliability assessment using failure mode and effect analysis (FMEA): survey and opportunity roadmap. International Journal of Engineering, Science and Technology, 3(7), 25-38.

Tang, J., Shi, T., Wu, X., Cao, H., Li, X., Hua, R., Tang, F., \& Yue, Y. (2015). The occurrence and distribution of antibiotics in Lake Chaohu, China: seasonal variation, potential source and risk assessment. Chemosphere, 122, 154-161.

Tay, K.M., \& Lim, C.P. (2010). Enhancing the failure mode and effect analysis methodology with fuzzy inference techniques. Journal of Intelligent \& Fuzzy Systems, 21(1-2), 135-146.

Teng, S.H.G., \& Ho, S.Y.M. (1996). Failure mode and effects analysis. International Journal of Quality \& Reliability Management, 13(5), 8-26.

Teoh, P.C., \& Case, K. (2004). Failure modes and effects analysis through knowledge modelling. Journal of Materials Processing Technology, 153, 253-260.

Throop, D.R., Malin, J.T., \& Fleming, L.D. (2001, March). Automated incremental design FMEA. In 2001 IEEE Aerospace Conference Proceedings (Cat. No. 01TH8542) (Vol. 7, pp. 7-3458). IEEE. Big Sky, USA.

Thurnes, C.M., Zeihsel, F., Visnepolschi, S., \& Hallfell, F. (2015). Using TRIZ to invent failures-concept and application to go beyond traditional FMEA. Procedia Engineering, 131, 426-450.

Tingdi, Z., Tiejun, S., Xiao, H., \& Linling, S. (2004, January). Intelligent FMEA based on model FIORN. In Annual Symposium Reliability and Maintainability, 2004-RAMS (pp. 386-390). IEEE. Los Angeles, USA. 
International Journal of Mathematical, Engineering and Management Sciences

Vol. 6, No. 1, 79-102, 2021

https://doi.org/10.33889/IJMEMS.2021.6.1.007

Tixier, J., Dusserre, G., Salvi, O., \& Gaston, D. (2002). Review of 62 risk analysis methodologies of industrial plants. Journal of Loss Prevention in the Process Industries, 15(4), 291-303.

Vahdani, B., Salimi, M., \& Charkhchian, M. (2015). A new FMEA method by integrating fuzzy belief structure and TOPSIS to improve risk evaluation process. The International Journal of Advanced Manufacturing Technology, 77(1-4), 357-368.

Van Bossuyt, D., Hoyle, C., Tumer, I.Y., \& Dong, A. (2012). Risk attitudes in risk-based design: considering risk attitude using utility theory in risk-based design. AIEDAM, 26(4), 393-406.

Vernez, D., Buchs, D.R., Pierrehumbert, G.E., \& Besrour, A. (2004). MORM—a petri net based model for assessing OH\&S risks in industrial processes: modeling qualitative aspects. Risk Analysis: An International Journal, 24(6), 1719-1735.

Wang, J., Sii, H.S., Yang, J.B., Pillay, A., Yu, D., Liu, J., Maistralis, E., \& Saajedi, A. (2004). Use of advances in technology for maritime risk assessment. Risk Analysis: An International Journal, 24(4), 1041-1063.

Wang, M.H. (2011, July). A cost-based FMEA decision tool for product quality design and management. In Proceedings of 2011 IEEE International Conference on Intelligence and Security Informatics (pp. 297-302). IEEE. Beijing, China.

Wang, Y.M., \& Elhag, T.M. (2007). A fuzzy group decision making approach for bridge risk assessment. Computers \& Industrial Engineering, 53(1), 137-148.

Wang, Y.M., Chin, K.S., Poon, G.K.K., \& Yang, J.B. (2009). Risk evaluation in failure mode and effects analysis using fuzzy weighted geometric mean. Expert Systems with Applications, 36(2), 1195-1207.

Wardani, N.U., \& Pharmatrisanti, A. (2011, July). Power transformer assessment adjusted to tropical environment and utility requirement. In Proceedings of the 2011 International Conference on Electrical Engineering and Informatics (pp. 1-4). IEEE. Bandung, Indonesia.

Wirawan, C., \& Ayu, A.P. (2014, December). TRIZ based approach to improve public bus service quality. In 2014 IEEE International Conference on Industrial Engineering and Engineering Management (pp. 793-797). IEEE. Bandar Sunway, Malaysia.

Wirth, R., Berthold, B., Krämer, A., \& Peter, G. (1996). Knowledge-based support of system analysis for the analysis of failure modes and effects. Engineering Applications of Artificial Intelligence, 9(3), 219-229.

Xiao, N., Huang, H.Z., Li, Y., He, L., \& Jin, T. (2011). Multiple failure modes analysis and weighted risk priority number evaluation in FMEA. Engineering Failure Analysis, 18(4), 1162-1170.

Yadav, O.P., Singh, N., \& Goel, P.S. (2006). Reliability demonstration test planning: a three dimensional consideration. Reliability Engineering \& System Safety, 91(8), 882-893.

Yang, C., Letourneau, S., Zaluski, M., \& Scarlett, E. (2010, January). APU FMEA validation and its application to fault identification. In ASME 2010 International Design Engineering Technical Conferences and Computers and Information in Engineering Conference (pp. 959-967). American Society of Mechanical Engineers Digital Collection. https://doi.org/10.1115/DETC2010-28438.

Yang, Z., Bonsall, S., \& Wang, J. (2009, July). A fuzzy bayesian reasoning method to realise interactive failure analysis. In 2009 8th International Conference on Reliability, Maintainability and Safety (pp. 403-406). IEEE. Chengdu, China.

Yasko, A., Babeshko, E., \& Kharchenko, V. (2016). FMEDA-based NPP I \& C systems safety assessment: toward to minimization of experts' decisions uncertainty. In 2016 24th International Conference on Nuclear Engineering. American Society of Mechanical Engineers Digital Collection, (pp. 147-154). Charlotte, USA. 
International Journal of Mathematical, Engineering and Management Sciences

Vol. 6, No. 1, 79-102, 2021

https://doi.org/10.33889/IJMEMS.2021.6.1.007

Yu, S., Liu, J., Yang, Q., \& Pan, M. (2011, June). A comparison of FMEA, AFMEA and FTA. In The Proceedings of 2011 9th International Conference on Reliability, Maintainability and Safety (pp. 954960). IEEE. Guiyang, China.

Zafiropoulos, E.P., \& Dialynas, E.N. (2005). Reliability prediction and failure mode effects and criticality analysis (FMECA) of electronic devices using fuzzy logic. International Journal of Quality \& Reliability Management, 22(2), 183-200.

Zambrano, L., Sublette, K., Duncan, K., \& Thoma, G. (2007). Probabilistic reliability modeling for oil exploration \& production (E\&P) facilities in the tallgrass prairie preserve. Risk Analysis: An International Journal, 27(5), 1323-1333.

Zeng, Z., Kang, R., Wen, M., \& Chen, Y. (2015, January). Measuring reliability during product development considering aleatory and epistemic uncertainty. In 2015 Annual Reliability and Maintainability Symposium (RAMS) (pp. 1-6). IEEE. Palm Harbor, USA.

Zhao, X., \& Zhu, Y. (2010, November). Research of FMEA knowledge sharing method based on ontology and the application in manufacturing process. In 2010 2nd International Workshop on Database Technology and Applications (pp. 1-4). IEEE. Wuhan, China.

Zhao, X., Ma, Y.B., Cai, R., Bai, X.L., \& Ning, L.Y. (2009, July). Research and application of intelligent quality control system based on FMEA repository. In 2009 International Conference on Information Technology and Computer Science (Vol. 2, pp. 514-517). IEEE. Kiev, Ukraine.

Zhou, N., Ma, J.W., Hu, B., \& Miao, S.W. (2012). Reliability tracing technique for power transformers using the fault tree analysis method. Power System Protection and Control, 40(19), 72-77. 